\title{
COPYRIGHT PROTEGTION FOR THE WORKS OF CREATIVE MEDIA FIEID OF SAE LECTURERS AND STUDENTS IN THE INSTANT GRATIFICATION ERA
}

\author{
RR. Ella Evrita $H$ \\ Faculty of Law, As-Syafi'iyah Islamic University, Indonesia \\ e-mail: e.evrita@sae.edu \\ Correspondence: e.evrita@sae.edu
}

Submitted: 31 October 2021, Revised: 13 November 2021, Accepted: 14 November 2021

\begin{abstract}
Abstrak. The protection of ideas or creativity on the work, especially the work of students and lecturers in the creative media field is still not maximized. This can be seen from the rampant piracy of works in the music, information technology, publishing, film, and animation industries. In addition, there are still other problems such as plagiarism of written works, and licensing, especially for the music, photography, and information technology industries. The purpose of this article is to find out how the impact of the instant gratification era on the ideas or creativity of students and lecturers in the field of creative media and copyright protection for the works of lecturers and students. Therefore, it is necessary to have a regulation related to the protection of the works of lecturers and students. The author uses the Normative Juridical research method. The results of the study indicate that the era of instant gratification that was born from technological advances can also have positive and negative impacts, and the protection of the works of lecturers and students who have not been commercialized and are still in the form of drafts that need to be developed further (not yet real) is still not maximized.
\end{abstract}

Keywords: copyright protection; creative media; instant gratification era 


\section{INTRODUCTION}

Today's world industry has entered the era of the digital generation, also known as Industry 4.0 generation, a trend in the industrial world that blends automation technology with cyber technology. Danrivanto Budhijanto said that the Fourth Industrial Revolution (Industrial Revolution 4.0) brought new challenges. This rapid Industrial Revolution 4.0 has had an impact on technology and social developments, therefore relying on government/regulator legislation and incentives to ensure the optimal results is a huge mistake (Budhijanto, n.d.).

The progressive development of Industry 4.0 must be balanced with the readiness of the community which is now known as Society 5.0. Society 5.0 envisions a new future for humanity that incorporates technology into all aspects of life. Japanese Prime Minister Shinzo Abe first introduced Society 5.0 era to balance technological progress with integrated social problemsolving. The balance of society is required to anticipate the rapid development of Industry 4.0 which continues to create artificial intelligence until the advent of a new era, namely the instant gratification era in the Industry 4.0 era (Budhijanto, n.d.)

In the Industry 4.0 era, human creativity and innovation related to the use of information technology inspired a new industry, namely the creative industry (Budhijanto, 2016). As a result of the emergence of this creative industry, a new business, known as a startup, began to come up. Startup businesses prioritize new ideas and provide solutions to problems for consumers. Because they rely on technology to help business growth, it is understandable if some people view startup businesses as tech companies (Sudaryat et al., 2020). Various startup businesses are also engaged in the creative industry, including Creasi, Vallet.ld, Eksisenter, Kreavi, Sribu, Tees, and others.

The creative industry is one of many sectors to boost the Indonesian economy. The Industrial Revolution 4.0 era made the creative economy a strategic choice to win global competition, as marked by continued innovation and creativity to improve economic added value through the capitalization of creative ideas. The creative economy contributes to the economy by increasing gross domestic product, creating jobs, and increasing exports. The document of RPJM for the Creative Economy published by the Ministry of Tourism and Creative Economy of the Republic of Indonesia stated that the creative economy calculated by Statistics Indonesia during the 2010-2013 period contributed $7.05 \%$ on average to Indonesia's gross domestic product. There are around 17 subsectors of the creative economy, including publishing, architecture, product design, fashion, interior design, visual communication design, applications and games, film, animation and video, photography, music, television and radio, performing arts, craft, culinary, arts, and advertising (Sudaryat et al., 2020).

In the process of creative industry, the essential aspect is input in the form of ideas, innovation, and creativity because the creative economy is a process of creating added value that evolved from the ability of creative people to create works 
and services from ideas and the use of science, including cultural heritage and technology. Therefore, creativity and innovation require legal protection in the era of information technology, instant gratification, Industry 4.0, and Society 5.0, which is the legal protection of intellectual property (Sudaryat et al., 2020).

Three related intellectual properties include copyright, trademark, and patent. Copyright is a form of intellectual property that protects works in the fields of science, art, and literature by prioritizing authenticity and requiring that the works have been created. A trademark is a form of intellectual property that is directly related to the trade context that functions as a differentiator between products, services, quality assurance, promotional facilities, and information about the origin of goods. Meanwhile, patents are intellectual property that protects creative and innovative works in the form of products and processes in the field of technology. (Jibir \& Abdu, 2021)

The protection of ideas or creativity on works, especially the works of students and lecturers in the creative media field is not fully realized. This can be seen from the rise of piracy in the music, information technology, publishing, film, and animation industries. There are also other issues such as plagiarism of written works, and licensing, particularly for the music, photography, and information technology industries. Weak law enforcement is one of the factors causing the low number of creative works registering Intellectual Property Rights (IPR) by the owners, including students and lecturers in the creative media field. Therefore, it is necessary to have a regulation related to the protection of the works of lecturers and students (Yasechko et al., 2020).

According to (Sari, 2019), Intellectual Property Rights (IPRs) are exclusive rights granted by a regulation to a person or group of people for their work. Every creative work that is born from a bright and useful thought for humans needs to be recognized and protected by law. (Anderson-Zorn \& Long, 2021) researching about yearbooks which are challenging digitization projects because they are likely to contain privacy-sensitive photographs and other information as well as potentially copyrighted content created by multiple parties. An understanding of state and federal privacy laws, such as FERPA, and the ethical obligations to preserve the privacy of individuals is essential to addressing multi-layered concerns for digital access. Therefore, based on the description of the background above, the problems that will be discussed in this article are as follows:

1. What is the impact of the instant gratification era on the ideas or creativity of students and lecturers in the creative media field?

2. How is the copyright protection for the works of SAE lecturers and students in the creative media field in the instant gratification era?

\section{MATERIALS AND METHODS}

The research method used in this paper was normative juridical, which is characterized as literature studies. Literature studies are required to collect the necessary legal materials, such as primary legal materials including the 1945 Constitution of the Republic of Indonesia (UUDN RI 1945) and Law Number 28 of 2014 concerning Copyright. Secondary 
390 | Copyright Protection for The Works of Sae Lecturers and Students in The Creative Media Field in The Instant Gratification Era

legal materials, such as books, legal scientific papers, and other written materials were used to explain some of the terms used in this paper (R. Indonesia, 2002) (P. R. Indonesia \& Nomor, 28 C.E.)

\section{DISCUSSION}

\section{The Impact of the Instant Gratification} Era on the Ideas or Creativity of Students and Lecturers in the Creative Media Field

Creative media according to the origin of the word consists of two words, including media and creative. (Clark \& Morrison, 2009) said that Media are generally defined as the means by which information is conveyed from one place to another. Etymologically, the word "media" is the plural form of "medium", which comes from the Latin "medius" meaning "middle". Meanwhile, the word "medium" in the Indonesian language can be interpreted as "between" or "moderate". Therefore, the notion of media can lead to something that delivers or forwards information (messages) between the source (messenger) and the recipient of the message. Based on this definition, it can be concluded that the media is a form or means that can be used in a process of presenting the information.

The word creative can mean a capacity (effort or ability) to produce or create something unique, solve a problem or do something different from the others (thinking outside the box) that drives other sectors (following innovation), and improves the quality of life. Creativity is strongly related to innovation and invention, indicating that creativity is a factor that drives the emergence of innovation in the creation of creative works by utilizing existing inventions. Based on the definitions of the words "media" and "creative", it can be said that creative media is an introduction to communication that can transmit information (messages) between sources (messengers) and message recipients through the elaboration of unique resources and efforts in creating solutions to a problem in the realm of visual communication (Annisa, 2021).

Technological advances brought progress to the industrial world which eventually emerge a new era in the form of the instant gratification era. By definition, instant gratification is a practice of avoiding short-term difficulties that have the potential to lead to long-term difficulties (Adam Sicinski, n.d.). It means that someone will always find an excuse not to do something because the process is tough even though they are aware and understand that the process will help them to achieve their goals or ideals in the future.

There are several reasons why people, including lecturers and students who are engaged in the creative industry/creative media, are addicted to instant gratification, including:

1) The desire to avoid procrastination; waiting is not pleasant. From an evolutionary perspective, humans have the instinct to reach what they want or to get the prize right away, and resisting that instinct is difficult. Evolution has given humans a strong desire to get things done quickly (Shahram Heshmat Ph.D., 2016).

2) Hatred of uncertainty; everyone hates uncertainty. For example, a student gets 
a task from a lecturer to write a scientific work. The student was unsure whether their scientific work would be appreciated by the lecturer and would result in good grades for them. The encouragement from the doubt/uncertainty had finally brought the student to plagiarize other people's scientific work on the internet and claim to be the result of their scientific work. What the student does is a form of instant gratification that is common in the realm of education, notably by ignoring a process (the process of writing scientific papers) and focusing solely on the results (getting good grades from the lecturers).

3) Emotions and impulsivity; Psychological conditions such as emotions and impulsivity are also one of the factors that encourage an instant lifestyle. For instance, a YouTuber feels fatigued and stressed because the video content he made was not popular. When they see the video content made by other successful and popular YouTubers, they immediately have a desire or impulsive nature to imitate (create similar content).

As with technological advancements that have a variety of impacts on human life, the instant gratification era generated by technological advances can also bring positive and negative impacts. The positive impact of instant gratification is that people can express their various ideas, creativity, or visions in creative applications such as YouTube, Tiktok, Instagram, writing applications, and others. They not only can express ideas, creativity, or visions, but they can also store all of the creative works for quite a long time. Furthermore, they will receive direct feedback or input when the work resulting from an idea or creativity is seen by a large number of people fast owing to sophisticated technology (Waldron, 1992)

The negative impact of instant gratification is the increase in plagiarism of one's ideas or creativity, including the work of lecturers and students engaged in creative media. The increase in plagiarism is caused by the low level of awareness to register their works to obtain intellectual property protection such as copyrights, patents, or trademarks because the process is difficult and takes a long time. People who work in the creative industry or creative media get lethargic to register their work because they are accustomed to the instant gratification era, which is all done instantly (Yahya, 2011).

Instant gratification provides convenience, practicality, and speed in today's life, but it comes at a very high cost, namely personality and learning opportunities. The instant gratification era leads us to be a generation that wants to be fast, avoids waiting, and prefers to skip processes that tend to be slow and difficult. It means that instant gratification drives us to be impatient and quick-tempered.

\section{Copyright Protection for the Works of SAE Lecturers and Students in the Creative Media Field in the Instant Gratification Era}

The protection of the works of SAE lecturers and students in the creative media field is highly needed, particularly the legal protection of intellectual property, including the recognition of rights. In 
392 | Copyright Protection for The Works of Sae Lecturers and Students in The Creative Media Field in The Instant Gratification Era

accordance with its essence, Intellectual Property Rights (IPR) are classified as individual intangible property rights. (Margono, 2015)

In addition to intellectual property, the term IPR also refers to intangible property, creative property, and incorporeal property. In France, people call it the propriete intellectuelle and the propriete industrielle. Meanwhile, in the Netherlands, it is usually called intelektuil property and industrial property (Djumhana \& Djubaedillah, 2014).

WIPO as an international organization that manages the field of Intellectual Property Rights explains intellectual property as Intellectual property (IP) refers to creations of the mind: inventions, literary and artistic works, and symbols, names, images, and designs used in commerce.

The WIPO definition indicates that the meaning of Intellectual Property refers to the creation of the mind in the form of inventions, literature, and works of art, symbols, names, images, and designs used in trade. Therefore, IPR can be interpreted as ownership of these objects. In a broader context, the meaning of rights contains the value of authority over an object which, if violated, will certainly bring harm to the owner, and it is in this context that IPR can be interpreted as a legal issue (May, 2006).

David I. Bainbridge defines intellectual property that Intellectual property is the collective name given to legal rights which protect the product of the human intellect. The term intellectual property seems to be the best available to cover that body of legal rights which arise from mental and artistic endeavor (Bainbridge, 2019).

The term Hak Kekayaan Intelektual
$(\mathrm{HKI})$ in the Indonesian language that means Intellectual Property Rights (IPR) is a change or revision of the term Hak Atas Kekayaan Intelektual or rights for intellectual properties. This revision is based on the Decree of the Minister of Law and Legislation of the Republic of Indonesia Number M. 03.PR.07.10 of 2000 and the Approval of the Minister of State for Empowerment of State Apparatuses, in letter Number 24/M/PAN/1/2000, stating that the term "Hak Kekayaan Intelektual" (without the word "Atas") can be abbreviated as "HKI" and the acronym "HKI" has been officially used. Therefore, it is no longer "Hak Atas Kekayaan Intelektual" (with the word "Atas") (Atsar, 2018)

Intellectual Property Rights is applied if human intellectual abilities have formed something that can be seen, heard, read, or used practically (Djumhana \& Djubaedillah, 2014). Intellectual Property Rights are classified as individual property rights that are intangible and special because these rights are only given to the owner or holder of the right in question for a particular period to obtain legal protection to publish, reproduce, distribute, and other works of their creation, or give permission to someone else to do it (Margono, 2015).

Intellectual Property Rights (IPR) is essentially a right that arises as a result of human intellectual abilities in various fields that produce a beneficial process or product to mankind (Sutedi, 2009). Intellectual Property Rights is an exclusive right within the scope of technology, science, or arts and literature. The ownership is not related to the goods but the results of human intellectual ability and 
creativity in the form of ideas or thoughts.

(Roisah, 2015)

IPR consists of several forms, which are copyright including rights related to copyright, and industrial property rights including trademarks and geographical indications, patents, industrial designs, integrated circuit layout designs, trade secrets, and protection of plant varieties. These forms of Intellectual Property Rights are classified as individual Intellectual Property Rights. Besides, there are communal Intellectual Property Rights such as traditional knowledge and traditional cultural expressions which are still being fought for to be recognized in the World Trade Organization (WTO) by the World Intellectual Property Organization (WIPO) (May, 2006).

Copyright is the type of IPR that is most commonly related to the expansion of the creative industry. The current law that regulates copyright is Law No. 28 of 2014 replacing Law No. 19 of 2002 concerning Copyright. Based on Article 1 number (1) of Law No. 28 of 2014 concerning Copyright, copyright is the exclusive right of the creator that emerges automatically based on declarative principles following the existence of works in tangible form. Creation is any creative work in the fields of science, art, and literature that is produced on the inspiration, ability, thought, imagination, speed, skill, or expertise expressed in a tangible form (P. R. Indonesia \& Nomor, 28 C.E.)

The exclusive rights of copyright include moral rights and economic rights. Exclusive rights are those that can only be used by the inventor or copyright holder. Moral rights are rights that are eternally attached to the inventor and cannot be transferred as long as the inventor is still alive. Moral rights are mentioned in Article 6 of the Berne Convention that The author shall have the right to claim authorship of the work and to object to any distortion, mutilation, or other modification of, or other derogatory action in relation to, the said work, which would be prejudicial to his honor or reputation (Suhl, 2001).

Moral rights are the personal rights of the creators/authors to be able to prevent changes to their works and to still be called the creators of the works. Moral rights describe the continuing relationship between the creators and their works although the economic control over the works is no longer exists because they have been fully handed over to the copyright holders or have passed the period of protection as stipulated in the Copyright Law.

The Copyright Law regulates moral rights in Articles 5 to 7. Based on Article 5 paragraph (1), moral rights are eternally attached to the creators to:

a Continue to include or not include their names on the copy related to the public use of the Work;

b Use their alias or pseudonyms;

c Change their creations according to the propriety in society;

d Change the title and sub-title of the creation; and

e Defend their rights in the event of a distortion, mutilation, and modification of the work, or anything detrimental to their honor or reputation.

Article 5 paragraphs 2 and 3 states that moral rights cannot be transferred as long as the creators are still alive, but the 
394 | Copyright Protection for The Works of Sae Lecturers and Students in The Creative Media Field in The Instant Gratification Era

exercise of the rights can be transferred by a will or other reasons according to the provisions of the legislation after the creators die. In the event of a transfer of the exercise of moral rights, the recipient may release or refuse the exercise of their rights provided that the release or rejection of the exercise of the right is stated in writing (Reglitz, 2020).

Based on Article 6 of the Copyright Law, to protect the moral rights as referred to in Article 5 paragraph (1), the Creators may have copyright management information; and/or copyright electronic information. Then, Article 7 of the Copyright Law states that copyright management information includes information on methods or systems that can identify the originality of the substance of the Works and their Creators; information code and access code. Copyright electronic information as referred to in Article 6 letter $b$ includes information regarding:

1) A Work, which appears and is attached electronically related to the activity of Announcement of Works;

2) The creators' names, alias or pseudonyms;

3) The creators as Copyright Holders;

4) The period and conditions of use of the Works;

5) Number; and

6) Information Code.

Copyright management information in paragraph (1) and copyright electronic information in paragraph (2) owned by the Creators are prohibited from being removed, changed, or damaged. Besides moral rights, copyright also contains economic rights. Economic rights are rights to benefit from copyrighted works. Article 8 of the Copyright Law states that economic rights are the exclusive rights of the Creators or Copyright Holders to receive economic benefits from the Works. Furthermore, Article 9 of the Copyright Law states that the Creators or Rights Holders as referred to in Article 8 has the economic rights to do:

a Publishing Works;

b Reproduction of Works in all its forms;

c Translation of Works;

d Adaptation, arrangement, or transformation of Works;

e Distribution of Works or copies;

$f$ Show of Works;

g Announcement of Works

$\mathrm{h}$ Communication of Works; and

i Rental of Works.

Any person exercising economic rights as referred to in paragraph (1) is required to obtain permission from the Creators or Copyright Holders (Article 9 paragraph (2)). Any person without permission from the Creators or Copyright Holders is prohibited from duplicating and/or commercially using the works (Article 9 paragraph (3)).

Economic protection of copyright for works in the form of photographic works, portraits, cinematographic works, video games, computer programs, the layout of written works, translations, interpretations, adaptations, anthology, data lines, adaptations, arrangements, modifications, and other works resulting from the transformation, translation, adaptation, arrangement, or modification of traditional cultural expressions, a compilation of works or data, both in a format that can be read by computer programs or other media and compilation of traditional cultural 
expressions on condition that the compilation is an original work according to Article 59 paragraph (1) of the Copyright Law is valid for 50 years from the date it was first announced. (AULIA, n.d.) said Protection for works of applied art is valid for 25 years from the first date of the announcement.

Creative media education is a vocational education that requires direct practice in learning. Students are required to create works every semester, both in groups and individually. The outcomes of the works produced of their learning are significant, and they are often presented in festivals and competitions to obtain awards from national and international communities. These works in the fields of Audio Engineering, Film Production, Music Business, and Interactive Animation, are not yet works that can be commercialized and are still in draft form to be developed further. However, the ideas and creativity of students and lecturers are aspects that need to be protected (Council, 2003).

IPR regulates the protection of the works of lecturers and students. Indeed, the government has issued Copyright Law No. 28 of 2014 to replace the Copyright Law No. 19 of 2002 whose positive impact can be felt. However, it has not been associated with vocational education institutions, particularly the creative media field and educational institutions like vocational education in the creative media field. This institution does not focus on protecting the copyrights of students and lecturers, as well as the education law. Therefore, the ideas or creativity of students and lecturers have not received appropriate protection because they are still in the form of drafts or designs (not yet in real form). This is in line with the provisions of Article 1 point 1 of Law No. 28 of 2014 which states that copyright is the exclusive right of a creator that arises automatically based on declarative principles after a work is manifested in a tangible form without reducing the restrictions pursuant to the provisions of laws and regulations $(\underline{P}, R$. Indonesia \& Nomor, 28 C.E.).

\section{CONCLUSION}

Instant gratification is a practice of avoiding short-term difficulties that have the potential to lead to long-term difficulties. As with technological advancements that have a variety of impacts on human life, the instant gratification era generated by technological advances can also bring positive and negative impacts. The positive impact of instant gratification is that people can express their various ideas, creativity, or visions in creative applications such as YouTube, Tiktok, Instagram, writing applications, and others. The negative impact of instant gratification is the increase in plagiarism of one's ideas or creativity, including the work of lecturers and students engaged in creative media. IPR regulates the protection of the works of lecturers and students. However, the ideas or creativity of students and lecturers have not received appropriate protection because they are still in the form of drafts or designs (not yet in real form). This is in accordance with the provisions of Article 1 point 1 of Law No. 28 of 2014 (P. R. Indonesia \& Nomor, 28 C.E.). 
396 | Copyright Protection for The Works of Sae Lecturers and Students in The Creative Media Field in The Instant Gratification Era

\section{REFERENCES}

Adam Sicinski. (n.d.). Do You Struggle With Instant Gratification? You Must Try These 5 Steps. IQ Matrix. https://blog.iqmatrix.com/instantgratification

Anderson-Zorn, A. K., \& Long, D. (2021). Digitize Your Yearbooks: Creating Digital Access While Considering Student Privacy and Other Legal Issues. Journal of Contemporary Archival Studies, 8(1), 14.

Annisa, C. M. (2021). LKP: Perancangan Media Kreatif Ramadhan Bersama Better Youth Foundation. Universitas Dinamika.

Atsar, A. (2018). Mengenal Lebih Dekat Hukum Hak Kekayaan Intelektual. Deepublish.

AULIA, R. (n.d.). Perlindungan Hukum Terhadap Pencipta Karya Fotografi Dalam Bentuk Watermark Menurut Undang-Undang Hak Cipta no. 28 tahun 2014 (Analis Putusan Mahkamah.

Bainbridge, D. I. (2019). Information technology and intellectual property law. Bloomsbury Professional.

Budhijanto, D. (n.d.). Yurisdiksi Virtual dalam Revolusi Industri 4.0. Kumparan. https://kumparan.com/danrivantobudhijanto/yurisdiksi-virtual-dalamrevolusi-industri-4-0-1qmwmNnVyYO

Clark, R. E., \& Morrison, G. R. (2009). Media and Learning-Definitions and Summary of Research, Do Media Influence the Cost and Access to Instruction.

Council, N. R. (2003). Strategic education research partnership. National Academies Press.

Djumhana, M., \& Djubaedillah, R. (2014). Hak Milik Intelektual.

Indonesia, P. R., \& Nomor, U.-U. R. I. (28 C.E.). Tahun 2014 Tentang Hak Cipta. Tambahan Lembaran Negara Nomor, 5599.

Indonesia, R. (2002). Undang-Undang Dasar Negara Republik Indonesia Tahun 1945. Sekretariat Jenderal MPR RI.

Jibir, A., \& Abdu, M. (2021). Human capital and propensity to protect intellectual properties as innovation output: The case of Nigerian manufacturing and service firms. Journal of the Knowledge Economy, 12(2), 595-619.

Margono, S. (2015). Hukum hak kekayaan intelektual (HKI): mencari konstruksi hukum kepemilikan komunal terhadap pengetahuan \& seni tradisional dalam sistem hak kekayaan intelektual (HKI) di Indonesia. Pustaka Reka Cipta.

May, C. (2006). The world intellectual property organization. New Political Economy, 11(3), 435-445.

Reglitz, M. (2020). The human right to free internet access. Journal of Applied Philosophy, 37(2), 314-331.

Roisah, K. (2015). Konsep Hukum Hak Kekayaan Intelektual: sejarah, pengertian dan filosofi pengakuan HKI dari masa ke masa. Setara Press.

Sari, R. (2019). hak atas kekayaan intelektual dalam dunia teknologi dan komunikasi. 
Shahram Heshmat Ph.D. (2016). 10 Reasons

We Rush for Immediate Gratification.

Sussex

Publishers.

https://www.psychologytoday.com/us

/blog/science-choice/201606/10-

reasons-we-rush-immediate-

gratification

Sudaryat, S., Sukarsa, D. E., \& Ramli, A. M. (2020). Perlindungan Kekayaan Intelektual Karya Kreatif dan Inovatif Bisnis Startup di Indonesia dalam Era Industri 4.0 Dan Society 5.0. ACTA DIURNAL Jurnal Ilmu Hukum Kenotariatan, 4(1), 68-82.

Suhl, N. C. (2001). Moral rights protection in the United States under the Berne Convention: A fictional work. Fordham Intell. Prop. Media \& Ent. L, 12, 1203.

Sutedi, A. (2009). Hak atas kekayaan intelektual. Sinar Grafika.

Waldron, J. (1992). From authors to copiers: individual rights and social values in intellectual property. Chi.-Kent L. Rev., 68,841 .

Yahya, I. (2011). Plagiarisme dan [karya] kita. Sarasehan Program Studi Agroteknologi Fakultas Pertanian UPN Veteran (HIm. 1-6). Yogyakarta: UPN Veteran.

Yasechko, S. V, lasechko, S., Skomorovskyi, V. B., Andronov, I. V, Zaitsev, O. L., \& Bortnik, O. H. (2020). Features Of The Subjective Civil Rights On Patent. 